\title{
Výzkumný záměr: čas na hodnocení
}

Vážení čtenáři,

od prvního čísla prvního ročníku byl Český finanční a účetní časopis vydáván v rámci řešení výzkumného záměru Rozvoj účetní a finanční teorie a její aplikace v praxi zinterdisciplinárního hlediska. Nicméně každý výzkumný projekt má svoji předepsanou dobu řešení a tak poslední den právě uplynulého roku 2011 skončila rovněž sedmiletá cesta plná radostí i strastí spojená s tímto výzkumným záměrem. Pro nás řešitele ted' nastává čas sumarizování dosažených výsledků, zhodnocení přínosů a sepsání závěrečné zprávy.

Návrh každého výzkumného projektu je vždy podáván s určitým cílem. Naším základním cílem bylo propojit jednotlivé úrovně vědeckého výzkumu od základního výzkumu založeného na modelovém řešení nákladů zastoupení a vymezení výchozích teoretických postulátů, k aplikovanému výzkumu spočívajícímu ve třech hlavních oblastech: v práci na národních i mezinárodních účetních a oceňovacích standardech; v empirických studiích týkajících se vývoje finančních a účetních veličin v České republice a v dalších zemích; a ve zpracování modelů informačního řízení a finančního rozhodování v podnikové sféře.

Z hlediska základního výzkumu tvoří hlavní výstup model nákladů zastoupení s nejdůležitějšími agenty a principály $\mathrm{v}$ českém ekonomickém, politickém a sociálním prostředí. V rámci finančního účetnictví byla prvotní pozornost zaměřena na oblast mezinárodní harmonizace účetnictví a dále na problematiku auditu, fúzí a akvizic, účetnictví neziskových organizací a informatizace $\mathrm{v}$ účetnictví. Prostřednictvím Národní účetní rady vstupoval řešitelský tým aktivně do procesu harmonizace a podílel se na tvorbě řady interpretací k českým účetním předpisům. Výzkum $\mathrm{v}$ oblasti manažerského účetnictví byl zaměřen na tvorbu a využití manažersky orientovaných informačních systémů za účelem zvýšení vypovídací schopnosti manažerského účetnictví a zlepšení informační podpory pro potřeby strategického řízení podniků. Výsledky bádání v případě financí a oceňování podniku přinesly především návrh českých oceňovacích standardů, rozpracování metodiky finančního rozhodování pro různé situace, konstrukce transferových cen a vlastní analytickou studii finančního hospodaření českých podniků.

Každý dosažený výsledek má nicméně dvě stránky: formální a obsahovou. $Z$ formálního hlediska lze zaznamenat 788 publikací zaregistrovaných v oficiálním Rejstříku informací o výsledcích, z toho 69 odborných knih, 289 článků v časopisech s oponentním řízením a 430 př́spěvků ve vědeckých sbornících. Řešitelský tým se podílel na organizování vědeckých konferencí a vydával dva vědecké časopisy, mimo jiné právě Český finanční a účetní časopis. Za dobu jeho šestileté existence bylo v celkem dvaceti čtyřech číslech uveřejněno 190 článků $\mathrm{s}$ oponentním ř́zením, 55 článků v podobě diskuse k odbornému tématu či polemiky s článkem jiných autorů, 10 recenzí a 12 článků informativního charakteru. Některé články vzbudily pozornost odborné veřejnosti a byly následně citovány $\mathrm{v}$ dalších časopisech, jiné články posloužily při výuce předmětů a jiné, jak už to bývá, upadly následně do zapomnění. Přesto však si dovolím tvrdit, že se redakční radě podařilo vždy udržet odpovídající úroveň článků a uvést časopis úspěšně do života.

Výzkumný záměr již skončil. Avšak stejně jako s koncem výzkumného záměru nekončí výzkumné ambice členů řešitelského týmu, nekončí ani vydávání Českého finančního a účetního časopisu. Od roku 2012 bude nově vydáván v rámci projektu Institucionální 
podpora na dlouhodobý koncepční rozvoj výzkumné organizace na Vysoké škole ekonomické v Praze.

\author{
prof. Ing. Petr Marek, CSc. \\ předseda redakční rady Českého finančního a účetního časopisu \\ a řešitel dnes již skončeného výzkumného záměru \\ Rozvoj účetní a finanční teorie \\ a její aplikace $v$ praxi z interdisciplinárního hlediska
}

